\title{
Proceeding
}

9th INSHS International Christmas Sport Scientific Conference, 4-6 December 2014. International Network of Sport and Health

Science. Szombathely, Hungary

\section{The level of general physical performance and physical development of 7 and 10-year-old boys and girls}

\author{
IVAN ČILLÍK , RASTISLAV KOLLÁR , JURAJ KREMNICKÝ , PAVOL PIVOVARNIČEK, MARTINA \\ MANDZÁKOVÁ \\ Department of Physical Education and Sport, Faculty of Arts, Matej Bel University in Banská Bystrica, Slovakia
}

\begin{abstract}
Čillík, I., Kollár, R., Kremnický, J., Pivovarniček, P., \& Mandzáková, M. (2015). The level of general physical performance and physical development of 7 and 10-year-old boys and girls. J. Hum. Sport Exerc., 9(Proc1), pp.S259-S268. This contribution deals with the level of general physical performance and physical development of 7 and 10-year-old pupils attending primary schools. The sample consisted of pupils from all primary schools in Banska Bystrica: 492 pupils attending the $1^{\text {st }}$ grade and 433 pupils attending the $4^{\text {th }}$ grade. The following indicators of general physical performance were monitored: sit-andreach, standing long jump, sit-ups in $30 \mathrm{~s}$, flexed arm hang, shuttle run $4 \times 10$ meters, endurance shuttle run. Also basic somatic indicators such as body height, body weight and BMI were found out. In both age categories we found out that male pupils achieved better level in five tests of general physical performance: standing long jump, sit-up, flexed arm hang, shuttle-run $4 \times 10 \mathrm{~m}$ and endurance shuttle-run. At the age of 7 , male pupils are statistically significantly better in three tests $(p<0.05)$ and at the age of 10 , they are better in four tests $(p<0.05)$. Girls achieve statistically significantly better level of trunk flexibility $(p<0.05)$. 7 -years old boys and girls achieve better level of joint flexibility than10-years old boys and girls. In other tests, the 10-year-old boys and girls are better. Key words: PHYSICAL EDUCATION, PRIMARY SCHOOLS, THE 1ST GRADE PUPILS, THE 4TH GRADE PUPILS, TESTING OF GENERAL PHYSICAL PERFORMANCE, SOMATIC INDICATORS
\end{abstract}

Corresponding author. Department of Physical Education and Sport, Faculty of Arts, Matej Bel University, Tajovského street 40, 97401 Banska Bystrica, Slovakia

E-mail: ivan.cillik@umb.sk

9th INSHS International Christmas Sport Scientific Conference, 4-6 December 2014. International Network of Sport and

Health Science. Szombathely, Hungary.

JOURNAL OF HUMAN SPORT \& EXERCISE ISSN 1988-5202

(c) Faculty of Education. University of Alicante

doi:10.14198/jhse.2015.10.Proc1.13 


\section{INTRODUCTION}

Generally, an unsatisfactory level of physical activities, general physical performance as well as the health of children is evident during the last period. In the past, but not long ago a number of measurements and testing of the level of general physical performance of school population was performed. Motor performance of young school-age children is in most motor skills developed parallelly with age. Differences between girls and boys are generally negligible. Boys consistently dominate in motor activities due to explosive power and speed when comparing them to girls. Girls are characterized by greater flexibility of the lower back (Malina et al., 2004; Suchomel, 2006; Ružbarská \& Turek, 2007). Minimum differences are shown, boys are taller and heavier (Gallahue \& Donnelly, 2003). Relatively small differences in body disposal allow girl and boys effectively and fully participate in physical activities of the same type. The age of 10 is considered to be the most favorable period for motor development. Therefore, children are able to perform more difficult coordination-based exercises. Gross motor skills tend to develop and are in advance with the respect to the development of fine motor skills (Haywood \& Getchel, 2005).

For evaluation of physical performance of the school population are used standardized test batteries e.g. EUROFIT (EUROFIT, 1988), UNIFIT (Měkota \& Kovář, 1995; Chytráčková, 2002), FITNESSGRAM (Cooper Institute, 1999), ACTIVITYGRAM (Cooper Institute, 2004). There also exist test batteries for the selection of talented individuals in sport (Brown, 2001). There are also known other test batteries for the assessment of a general physical performance (Šimonek, 2012). These mentioned test batteries are, by their nature and normative way of assessment of the test results, focused on the performance component of physical fitness.

In Slovakia, there has been realized numerous studies dealing with physical development and general physical performance of pupils (Havlíček, 1988; Moravec, 1990; Kasa, 1997; Moravec et al., 1996; Turek, 1999; Jančoková, et al., 2002; Trunečková, et al., 2003; Ružbarská \& Turek, 2007). The results are different, as well as the test batteries, abundance and representativeness of samples. The test battery EUROFIT is mostly used for detection of general physical performance and physical development. Based on the information of the previous reviews of physical fitness and physical performance of children, we conclude that the innovation of motor tests and their verification should lead to a simplification of diagnosis. Therefore, we applied a set of tests that cover the full range of general physical performance, but by reducing the number of test items in comparing with the test battery EUROFIT.

Our work deals with the issue in a group of children from Banská Bystrica. The aim of this contribution is to find out the level of general physical performance and the level of physical development of the 1stgrade and the 4thgrade pupils in Banská Bystrica. The project is an agreement on cooperation between the town Banská Bystrica and Matej Bel University. This project was organized by Department of Physical Education and Sport, Faculty of Arts.

This contribution was written with the support of grant project KEGA 039UMB-4/2014 The innovation of tests of general physical performance of the school population between 6-15 years in region Banská Bystrica. 


\section{MATERIAL AND METHODS}

There are 12 public schools in Banská Bystrica. One of the schools is without a gym; therefore these pupils were not tested. Overall, we tested 492 pupils out of 572 pupils attending the $1^{\text {st }}$ grade and this is $86 \%$. Remaining $14 \%$ were not tested because of the absence on teaching process or they could not exercise mainly because of the health reasons. Tested pupils were from eleven public schools. They were from all classes of the 1 st grades of schools in the number of 252 boys and 240 girls. The average age of tested boys was $7.39 \pm 0.43$ decimal years during the measuring and the average age of tested girls was $7.24 \pm 0.34$ decimal years. So, the group of tested boys was older about 0.14 years.

Overall, we tested 433 pupils out of 579 pupils attending the 4 th grade and this is $75 \%$. Remaining $25 \%$ were not tested because of the absence on teaching process or they could not exercise mainly because of the health reasons. Tested pupils were from eleven public schools. They were from all classes of the 4th grade of schools in the number of 220 boys and 213 girls. The average age of tested boys was $10.37 \pm 0.44$ decimal years during the measuring and the average age of tested girls was $10.21 \pm 0.4$ decimal years. So, the group of tested boys was older about 0.16 years.

Measurements were made by teachers from the Department of Physical Education and Sport, Faculty of Arts, with the help of PhD students, Master and Bachelor students in April-June 2013 - the first grade and in April-June 2014 - the fourth grade. Measurements were made in accordance with daily biorhythms (Jančoková, 2000) always in the morning from 8 to 12 o'clock under the standard conditions of the gym at school, which pupils have attended. As a rule, one class was tested during one lesson.

Measuring process:

1. After arriving to the gym pupils received race numbers and they became familiar with the aim of the research.

2. Asking for basic identification data of tested pupils: name, date of birth, involvement in organized physical and sport activities. Basic identification data were provided by classroom teachers.

3. Measuring of the level of physical development: body height, body weight. BMI was calculated on the basis of this.

Body height - measuring according to the methodology of Moravec et al. (2002) with the accuracy of 0.5 $\mathrm{cm}$.

Body weight - measuring using a digital scale, with the accuracy of $0.1 \mathrm{~kg}$.

4. Warming-up (3 $\mathrm{min})$ and stretching (5 $\mathrm{min})$.

5. Measuring of the level of general physical performance: sit-and-reach, standing long jump, sit-ups, flexed arm hang, shuttle run $4 \times 10$ meters, and endurance shuttle run.

We applied a set of tests that cover the full range of general physical performance, but by reducing the number of test items in comparing with the mentioned test batteries. All the tests, sit-and-reach test, standing long jump, sit-ups, flexed arm hang and endrance shuttle run test, were performed according to the methodology (Moravec et al., 2002). Shuttle run $4 \times 10 \mathrm{~m}$ was performed according to the methodology (Čillik et al., 2013). The task was to cross the opposite or starting line with both feet. The time required to overcome $4 \times 10 \mathrm{~m}$ sections is recorded with the accuracy of $0.1 \mathrm{~s}$. The order of the tests was not strictly followed due to time, but endurance shuttle run was always performed as the last one. 
We used the chi-square goodness of a fit test to verify the representativeness of the subjects by sex. The representativeness was verified for standard use $5 \%$ significance level $(\alpha=0.05)$. We did not reject the representativeness of sex selection: $1^{\text {st }}$ grade $(p$-value $=0.804), 4^{\text {th }}$ grade $(p$-value $=0.136)$.

We used a T-test for independent subjects to verify the difference in the performance of boys and gilrs.

Statistically significant difference in exercise performance was tested in:

-the level of general physical performance (in all implemented tests) between boys and girls.

-the level of physical development (body height, body weight, BMI) between boys and girls.

Statistical analysis was performed by using the software IBM SPSS Statistic 19.0.0.

We also used the following basic statistical characteristics of central tendency and dispersion when evaluating the results: arithmetic average (x), standard deviation (SD), minimum measured values (min) and maximum measured values (max) and percentages (\%). We used basic logical methods to evaluate and interpret the results.

We used Cohen's coefficient $(d)$ between monitored groups of boys and girls to calculate the size of the effect size (Ellis, 2009). Coefficient was interpreted as follows: $d=0.20$ - low effect, $d=0.50$ - medium effect, $d=0.80-$ high effect (Cohen, 1992).

\section{RESULTS}

Results show a different level of general physical performance of 7-years old boys and girls (Table 1, 2, 3). Girls achieve on average better level of trunk flexibility which was determined using a sit-and-reach test. Contrary, boys achieve better average values in explosive power of lower limbs (standing long jump), in dynamic endurance strength of abdominal and hip-thigh muscles (sit-ups), endurance strength of upper limb (flexed arm hang), running speed with changes of direction (shuttle run $4 \times 10$ meters) and running endurance capacity (endurance shuttle run). We recorded statistically significant difference in the following tests: standing long jump, sit-ups and shuttle run $4 \times 10$ meters in favor of boys and in the sit-and-reach test in favor of girls.

Table 1. Monitored indicators of genera physical performance and physical development in group of 7 years old boys (B)

\begin{tabular}{|c|c|c|c|c|c|c|c|c|c|c|}
\hline B & AGE & SRT & SLJ & SUT & FAH & $4 \times 10$ & ESR & $\mathrm{BH}$ & BW & BMI \\
\hline & & $(\mathrm{cm})$ & $(\mathrm{cm})$ & (n) & (s) & (s) & (n) & $(\mathrm{cm})$ & $(\mathrm{kg})$ & (i) \\
\hline$x$ & 7.39 & 17.57 & 121.27 & 15.23 & 16.88 & 14.13 & 21.47 & 127.33 & 26.84 & 16.38 \\
\hline $\mathrm{SD}$ & 0.43 & 5.81 & 18.95 & 4.90 & 17.07 & 1.29 & 11.79 & 5.82 & 5.30 & 2.22 \\
\hline $\min$ & 6.68 & 2 & 68 & 0 & 0 & 11.4 & 3 & 111.00 & 17.90 & 12.40 \\
\hline $\max$ & 9.28 & 31 & 179 & 31 & 89 & 19.7 & 66 & 143.50 & 48.00 & 26.30 \\
\hline
\end{tabular}

Notes: SRT - Sit-and-reach test: SLJ - Standing long jump; SUT - sit ups; FAH - Flexed arm hang; $4 \times 10$ - the shuttlr run 4 x 10 m, ESR - Endurance shuttle run; BH - Body height; BW - Body weight;

$\mathrm{BMI}$ - body mass index 
Table 2. Monitored indicators of general physical performance and physical development in group of 7 years oldgirls $(G)$

\begin{tabular}{|c|c|c|c|c|c|c|c|c|c|c|}
\hline G & AGE & SRT & SLJ & SUT & FAH & $4 \times 10$ & ESR & $\mathrm{BH}$ & BW & BMI \\
\hline & & $(\mathrm{cm})$ & $(\mathrm{cm})$ & (n) & (s) & (s) & (n) & $(\mathrm{cm})$ & $(\mathrm{kg})$ & (i) \\
\hline$x$ & 7.25 & 20.83 & 111.49 & 13.07 & 16 & 14.54 & 19.87 & 125.62 & 25.72 & 16.16 \\
\hline SD & 0.34 & 5.08 & 18.39 & 5.59 & 14.43 & 1.14 & 10.2 & 6.22 & 5.81 & 2.57 \\
\hline $\min$ & 6.14 & 5 & 57 & 0 & 0 & 12.0 & 3 & 111.50 & 14.30 & 11.60 \\
\hline $\max$ & 8.45 & 35 & 165 & 29 & 90 & 18.7 & 67 & 143.00 & 55.90 & 33.10 \\
\hline
\end{tabular}

Notes: SRT - Sit and reach test; SLJ - Standing long jump; SUT - Sit-ups; FAH - Flexed am hand; 4x10 the shuttlen run 4 × $10 \mathrm{~m}$; ESR - Endurance shuttle run, $\mathrm{BH}$ - body height; $\mathrm{BW}$ - body weight; $\mathrm{BMI}$ - body mass index

Table 3. Statistical evaluation of differences of 7 years old boys and girls in the indicators of general physical performance and physical development

\begin{tabular}{|c|c|c|c|c|c|c|c|c|c|}
\hline Difference & SRT & SLJ & SUT & $\mathrm{FAH}$ & $4 \times 10$ & ESR & $\mathrm{BH}$ & BW & BMI \\
\hline$B-G$ & $(\mathrm{~cm})$ & $(\mathrm{cm})$ & (n) & (s) & (s) & (n) & $(\mathrm{cm})$ & $(\mathrm{kg})$ & (i) \\
\hline$X_{B}-X_{G}$ & $-3.26^{*}$ & $9.78^{*}$ & $2.16^{*}$ & 0.88 & $-0.41 *$ & 1.60 & $1.71 *$ & $1.12^{*}$ & 0.22 \\
\hline $\mathrm{ES}_{\text {value }}$ & 0.60 & 0.56 & 0.44 & 0.34 & 0.42 & 0.19 & 0.36 & 0.20 & 0 \\
\hline $\mathrm{ES}_{\text {tevel }}$ & mediu & medium & low & low & low & low & low & low & low \\
\hline
\end{tabular}

Notes: SRT - Sit-and- reach test; SLJ - Standing long jump; SUT - sit-ups; FAH - Flexed arm hang; $4 \times 10$ - the shuttle run $4 \times 10$ m; ESR - Endurance shuttle run; BH - body height; BW - body weight;

$\mathrm{BMI}$ - body mass index; $\mathrm{X}_{\mathrm{b}}-\mathrm{X}_{G}$ - difference between the average of boys and girls, ${ }^{*}$ statistically significant difference ( $p$-value $<0.05)$; ES - effect size.

Referring to the level of minimum and maximum performance, differences in used tests are not as clear as the average values. The girls achieved the best results in the sit-and-reach test, flexed arm hang and endurance shuttle run. The boys achieved the best performance in the following tests: standing long jump, sit-ups and shuttle run $4 \times 10$ meters. The girls achieved the worst result in standing long jump and the boys in the sit-and-reach test and shuttle run $4 \times 10$ meters. There are three tests in which the girls and boys achieved the same worst performance: sit-ups, flexed arm hang and endurance shuttle run. In two of these tests, sit-ups and flexed arm hang, we recorded zero values. It means, in both groups were individuals who had not done one cycle in the sit-ups test and did not maintain the desired position in the flexed arm hang test. 
We also recorded higher average somatic indicators in a group of boys-body height (boys were on average higher about $1.71 \mathrm{~cm}$ ), body weight (boys were on average heavier about $1.12 \mathrm{~kg}$ ) and in BMl about 0.22 (Table 1, 2, 3). Statistically significant difference $(p$-value $<0,05)$ was found in body height and weight in favor of boys. Statistically significant difference was not recorded in BMI.

Cohen's coefficient reached a moderate dependence only in two indicators: in sit-and-reach test in favour of gilrs and standing long jump in favour of boys. In other indicators there was observed little effect (Table 3).

Results show a different level of general physical performance of 10-years old boys and girls (Table 4, 5, 6). Girls achieve on average better level of trunk flexibility which was determined using a sit-and-reach test. Contrary, boys achieve better average values in explosive power of lower limbs(standing long jump), in dynamic endurance strength of abdominal and hip-thigh muscles (sit-ups), static, endurance strength of upper limb (flexed arm hang), running speed with changes of direction (shuttle run $4 \times 10$ meters) and running endurance capacity (endurance shuttle run). We recorded statistically significant difference in the following tests: standing long jump, sit-ups and shuttle run $4 \times 10$ meters and endurance shuttle run in favor of boys and in the sit-and-reach test in favor of girls.

Referring to the level of maximum performance there are differences similar to the average values. The girls achieved the best results in the sit-and-reach test; the boys achieved better level in other tests.In the level of minimum performance there are not differences in monitored tests as clear as in the average values. The girls achieved the worst results in sit-up test and in endurance shuttle run test. The boys achieved the worst results in sit-and-reach test, standing log jump and shuttle run $4 \times 10$ meters. the girls and boys achieved the same worst performance in the flexed arm hang test: 0 . This means that in both groups there were individuals who did not maintain the desired position in the flexed arm hang test.

When comparing with the girls, in boys we recorded higher average somatic indicators - body height (boys were on average higher about $0.71 \mathrm{~cm}$ ), body weight (boys were on average heavier about $2.33 \mathrm{~kg}$ ) and in BMI about 0.96 (Tables $4,5,6$ ). Statistically significant difference ( $p$-value $<0.05$ ) was found in body weight and BMI in favor of boys.

Table 4. Monitored indicators of general physical performance and physical development in a group of 10-years old boys (B)

\begin{tabular}{|l|c|l|l|l|l|l|l|l|l|l|}
\hline $\mathrm{B}$ & AGE & SRT & SLJ & SUT & FAH & $4 \times 10$ & ESR & BH & BW & BMI \\
\hline & & $(\mathrm{cm})$ & $(\mathrm{cm})$ & $(\mathrm{n})$ & $(\mathrm{s})$ & $(\mathrm{s})$ & $(\mathrm{n})$ & $(\mathrm{cm})$ & $(\mathrm{kg})$ & $(\mathrm{i})$ \\
\hline $\mathrm{x}$ & 10.37 & 16.28 & 151.93 & 19.75 & 25.45 & 12.8 & 37.08 & 144.75 & 38.78 & 18.36 \\
\hline $\mathrm{SD}$ & 0.44 & 6.55 & 22.01 & 4.97 & 22.92 & 1.31 & 17.28 & 6.85 & 9.24 & 3.42 \\
\hline $\min$ & 9.57 & 0 & 66 & 6 & 0 & 10.2 & 9 & 125 & 22.3 & 13.2 \\
\hline $\max$ & 12.9 & 31 & 216 & 37 & 115 & 17.5 & 94 & 164.5 & 75 & 31.02 \\
\hline
\end{tabular}

Notes: SRT - Sit-and-reach test; SLJ - Standing long jump; SUT - sit-ups; FAH - Flexed arm hang; 4x10

- the shuttle run 4 × 10 m; ESR - Endurances shuttle run; $\mathrm{BH}$ - body height; BW - body weight; BMI body mass index 
Table 5. Monitored indicators of general physical performance and physical development in a group of 10-years old girls $(G)$

\begin{tabular}{|l|c|l|l|l|l|l|l|l|l|l|}
\hline G & AGE & SRT & SL & SUT & FAH & $4 \times 10$ & ESR & BH & BW & BMI \\
\hline & & $(\mathrm{cm})$ & $(\mathrm{cm})$ & $(\mathrm{n})$ & $(\mathrm{s})$ & $(\mathrm{s})$ & $(\mathrm{n})$ & $(\mathrm{cm})$ & $(\mathrm{kg})$ & $(\mathrm{i})$ \\
\hline $\mathrm{x}$ & 10.21 & 20.62 & 144.06 & 17.86 & 24.18 & 13.34 & 29.51 & 144.04 & 36.45 & 17.4 \\
\hline SD & 0.4 & 6,46 & 18,51 & 4,44 & 19,22 & 1,03 & 13,46 & 6,63 & 8,23 & 2,91 \\
\hline $\min$ & 9.48 & 5 & 85 & 2 & 0 & 10.6 & 5 & 122 & 20 & 12.9 \\
\hline $\max$ & 12.34 & 36 & 199 & 35 & 81 & 16.2 & 85 & 162 & 67 & 28.5 \\
\hline
\end{tabular}

Notes: SRT - sit-and-reach test; SLJ - Standing long jump; SUT - sit-ups; $\overline{F A H}$ - Flexed arm hang; 4x10 - the shuttle run 4 × 10 m; ESR - Endurance shuttle run, $\mathrm{BH}$ - body height, BW - body weight; $\mathrm{BMI}$ body mass index

Table 6. Statistical evaluation of differences of 10-years old boys and girls in the in indicators of general physical performance and physical development

\begin{tabular}{|c|c|c|c|c|c|c|c|c|c|}
\hline Difference & SRT & SLJ & SUT & FAH & $4 \times 10$ & ESR & $\mathrm{BH}$ & BW & BMI \\
\hline$B-G$ & $(\mathrm{~cm})$ & $(\mathrm{cm})$ & (n) & (s) & (s) & (n) & $(\mathrm{cm})$ & (kg) & (i) \\
\hline $\mathrm{X}_{\mathrm{B}}-\mathrm{X}_{\mathrm{G}}$ & $-4.34 *$ & $7.87 *$ & $1.89 *$ & 1.7 & $-0.54^{*}$ & $7.57 *$ & 0.71 & $2.33 *$ & $0.96 *$ \\
\hline $\mathrm{ES}_{\text {value }}$ & 0.67 & 0.35 & 0.50 & 0.05 & 0.56 & 0.53 & 0 & 0.23 & 0.39 \\
\hline $\mathrm{ES}_{\text {level }}$ & $\begin{array}{r}\text { mediu } \\
\text { m }\end{array}$ & low & $\begin{array}{r}\text { mediu } \\
\text { m }\end{array}$ & low & $\begin{array}{c}\text { mediu } \\
\text { m }\end{array}$ & $\begin{array}{r}\text { mediu } \\
\mathrm{m}\end{array}$ & low & low & low \\
\hline
\end{tabular}

Notes: SRT - Sit-and-reach test; SLJ - Standing long jump; SUT - Sit-ups; FAH - Flexed arm hang; 4x10 - the shuttle run $4 \times 10$ m; ESR - Endurance shuttle run; $\mathrm{BH}$ - body height; BW - body weight; $\mathrm{BMI}$ body mass index; $\mathrm{X}_{\mathrm{b}}-\mathrm{X}_{G}-$ difference between the average of boys and girls, ${ }^{*}$ statistically significant difference $(P$-value< 0.05); ES - Effect size

In group of 10-year-old children we found out in Cohen's coefficient a moderate dependence in the sit-andreach test in favour of girls and in 3 tests in favour of boys: sit-ups, shuttle run $4 \times 10 \mathrm{~m}$ and endurance shuttle run test. In other indicators there was observed little effect (Table 6).

\section{DISCUSSION}

When comparing the group of boys and girls, we found out that 7 and 10-year-old boys reach better level of general physical performance than girls in the following five tests: standing long jump, sit-and-reach test, flexed arm hang, shuttle run $4 \times 10 \mathrm{~m}$ and endurance shuttle run. At the age of 7 , the differences are statistically significant in three tests and at the age of 10 , the differences are statistically significant in four 
tests. At the age of 7 and 10, the girls reach statistically better level of performance in trunk flexibility than boys. On this basis, we state a similar development of the level of general physical performance in boys and girls aged 7-10 years. Our results are consistant with those of Moravec (1990) who mentions that the results of boys in the tests of general physical performance according to EUROFIT are significantlly higher than the results of girls, except trunk flexibility. In contrast, Kučera et al. (2011) state that at the age of 9-11 years, the sex differences are not significantlly shown in the performance. These authors indicate that at the age of 8-12 years there are the largest increases in trunk flexibility, which was not confirmed by us because 10- year old boys and girls achieve lower level in the sit-and-reach test than 7 -year-old boys and girls.

In the indicators of physical development, the boys reach higher values than girls in all three monitored indicators. In two indicators, the differences are statistically significant but the substantive significance of the differences is minimal. The finding of Turek (1999) about the biological acceleration in 10-year-old girls from Eastern Slovakia, and the finding of Moravec et al. (2002) who recorded higher body height in 10year-old girls of Slovak population than it was in boys, were not confirmed in our tested subjects.

We used two test batteries in this contribution - EUROFIT and UNIFIT. Based on analysis of numerically limited files, it was concluded that the diagnosis of motor skills of children younger school age is characterized by excessive width of "diagnostic coverage", e.g. Turek $(1996,1999)$. Therefore, we wanted to apply a battery that would cover the whole range of general physical performance, but through reducing the number of test items. We have omitted the test "flamingo" because of its lack of validity and questionable implementation in younger school age as the author Turek (1999) claims. Whereas speed capabilities were investigated using another test (shuttle run $4 \times 10$ meters), we omitted plate tapping which is used to measure frequency speed of arm. We also omitted a hand dynamometer because we used the flexed arm hang test to find out a static strength of upper limbs. Instead of $10 \times 5 \mathrm{~m}$ we used shuttle run test $4 \times 10 \mathrm{~m}$, considering its duration and easier implementation. Although, the test $4 \times 10 \mathrm{~m}$ can be found in the battery UNIFIT, we simplified it considering the age of children. Our test battery proved to be an adequate for 7 and 10-year-old children. Moreover, it is almost identical to the battery of Brown (2001) for identification of sport talent. Thus, it could be also used for the selection of physically talented children for sport.

\section{CONCLUSIONS}

Boys at the age of 7 and 10 years reach higher level of general physical performance than girls at the same age in 5 tests: standing long jump, sit-ups, flexed arm hang, shuttle run $4 \times 10 \mathrm{~m}$ and endurance shuttle. Contrary, girls are better in sit-and-reach test statistically significant. In all of the indicators of physical performance (body high, body weight and BMI) boys achieved higher values than girls at the age of 7 and 10 years. Differences in general physical performance correspond to differences in physical development, except trunk flexibility. With a tendency of increasing differences in favor of boys in tests for speed-strength and endurance capabilities. Seven years old boys and girls achieve better level of trunk flexibility than ten years old boys and girls. Ten years old boys and girls are better in other tests.

The set of tests which we used affects the full range of general physical performance. In terms of coordination abilities, 7 and 10-year-old children are able to pass tests at appropriate technical level. When there is a sufficient number of examiners (6-8) in one class (20-25 pupils), it can be implemented in one lesson. It is not challenging the spatial and material support because it does not require special devices that are not in primary schools. 


\section{REFERENCES}

1. Brown, J. (2001) Sports talent. Champaign: Human Kinetics.

2. Cohen, J. (1992) Statistics a power primer. Psychology Bulletin, 112(1), p.p.115-159.

3. Cooper (1999) INSTITUTE. FITNESSGRAM. Test administration manual. $2^{\text {nd }}$ revised ed. Champaign, IL: Human Kinetics.

4. Cooper (2004) Institute. FITNESSGRAM/ACTIVITYGRAM. Test administration manual. $3^{\text {nd }}$ ed. Champaign, IL: Human Kinetics.

5. Čillik, I. (2012/2013) Všeobecná pohybová výkonnost' a telesný vývin žiakov 1. ročníka základných škôl v Banskej Bystrici v školskom roku. Banská Bystrica: Fakulta humanitných vied Univerzity Mateja Bela, pp.102.

6. Ellis, P.D. "Effect size calculators," website. [http://www.polyu.edu.hk/mm/effect sizefaqs/calculator/calculator.htm/]accessed on [20/11/2014]

7. Eurofit. (1988) European Tests of Physical Fitness. Rome: Council of Europe, Comittee for the Development and Sport, pp.180.

8. Gallahue, D. L., \& Donnelly F. C. (2003) Development at physical education for all children. Champaign, IL: Human Kinetics.

9. Havliček, I.(1988) Relatívna pohybová výkonnost' 7-18 ročnej mládeže $v$ ČSFR a jej porovnanie $\checkmark$ rokoch. p.p 1966-1987. Bratislava: Ministerstvo školstva a mládeže slovenskej republiky.

10. Haywood, K. M., \& Getchel, N. N.(2005) Lifespan motor development. Champaign, IL: Human Kinetics.

11. Chytráčková, J.(2002) Unifitest. Praha: Fakulta tělesné výchovy a sportu, Karlova univerzita. 66 p.

12. Jančoková, L'.(2002) Monitorovanie telesného rozvoja, funkčného stavu a pohybovej výkonnosti žiakov základných škôl v Banskobystrickom kraji na začiatku nového tisícročia. Banská Bystrica: Fakulta humanitných vied Univerzity Mateja Bela. $236 \mathrm{~s}$.

13. Jančoková, L'. (2002) Monitorovanie telesného rozvoja, funkčného stavu a pohybovej výkonnosti žiakov základných škôl v Banskobystrickom kraji na začiatku nového tisícročia. Banská Bystrica: Fakulta humanitných vied Univerzity Mateja Bela. pp.120.

14. Kasa, J. (1997) Hodnotenie telesného rozvoja a pohybovej výkonnosti 6-12 ročných detí. In Telesný rozvoj a pohybová výkonnost' detí a mládeže. Prešov: Východoslovenská spoločnost' vedeckej spoločnosti pre telesnú výchovu a šport, pp.211-215.

15. Kučera, M., Kolář, P., Dylevský, I. et al. (2011) Dítě, sport a zdraví. Praha: Galén. p.p.190.

16. Malina, R. M., Bouchard, C., \& Bar-Or, O. (2004) Growth, maturation, and physical activity. Champaign, IL: Human Kinetics.

17. Měkota, K., Kovář, R. et al. (1995) UNIFITTEST. Tests and Norms of Motor Performance and Physical Fitness in Youth and in Adult Age. (6-60) Olomouc: Palacky University.

18. Moravec, R.(1990)Telesný, funkčný rozvoj a pohybová výkonnost' 7-18 ročnej mládeže v ČSFR. Bratislava : Ministerstvo školstva a mládeže slovenskej republiky.

19. Moravec, R., Kammiller, T., Sedláček, J. (2002) Eurofit. Telesný rozvoj a pohybová výkonnost' školskej populácie na Slovensku. Bratislava: Slovenská vedecká spoločnost’ pre telesnú výchovu a šport. pp.181.

20. Ružbarská, I., \& Turek, M. (2007) Kondičné a koordinačné schopnosti v motorike detí predškolského a mladšieho školského veku. Prešov: Fakulta športu PU, pp.142.

21. Suchomel, A. (2006) Tělesně nezdatné deti školniho věku. Liberec: Technická univerzita.

22. Šimonek, J. (2012) Testy pohybových schopností. Nitra : Dominant, pp.195. 
23. Trunečková, E. (2003) Športové záujmy žiakov a učitel'ov 1. stupňa základných škôl a ich somatická a funkčná charakteristika. Banská Bystrica: Pedagogická fakulta Univerzity Mateja Bela.

24. Turek, M. (1996) Application of „EUROFIT“. Tests of Younger School Age Pupils. In: Conference Proceedings $4^{\text {th }}$ International Scientific Conference "Sport Kinetics 95". Prague: Charles University, pp.479-483.

25. Turek, M. (1999) Telesný vývin a pohybová výkonnost' detí mladšieho školského veku. Prešov: Východoslovenská spoločnost' vedeckej spoločnosti pre telesnú výchovu a šport. pp.112. 